\title{
Anaerobic Methanotrophic Archaea of the ANME-2d Cluster Are Active in a Low-sulfate, Iron-rich Freshwater Sediment
}

\section{OPEN ACCESS}

Edited by:

Télesphore Sime-Ngando, Centre National de la Recherche

Scientifique, France

Reviewed by:

Gunter Wegener,

Max Planck Institute for Marine Microbiology (MPG), Germany

Sabine Kasten

Alfred Wegener Institute Helmholtz Centre for Polar and Marine Research

(AWI), Germany

*Correspondence:

Hannah S. Weber

hannah@biology.sdu.dk

tPresent address:

Kirsten S. Habicht

Unisense AVS, Århus, Denmark

Specialty section: This article was submitted to Aquatic Microbiology, a section of the journal

Frontiers in Microbiology

Received: 07 December 2016 Accepted: 27 March 2017 Published: 12 April 2017

Citation:

Weber HS, Habicht KS and Thamdrup B (2017) Anaerobic Methanotrophic Archaea of the ANME-2d Cluster Are Active in a Low-sulfate, Iron-rich Freshwater Sediment. Front. Microbiol. 8:619. doi: 10.3389/fmicb.2017.00619

\section{Hannah S. Weber*, Kirsten S. Habicht ${ }^{\dagger}$ and Bo Thamdrup \\ Nordic Center for Earth Evolution and Department of Biology, University of Southern Denmark, Odense, Denmark}

ANaerobic MEthanotrophic (ANME) archaea remove the greenhouse gas methane from anoxic environments and diminish its flux to the atmosphere. High methane removal efficiencies are well documented in marine environments, whereas anaerobic oxidation of methane (AOM) was only recently indicated as an important methane sink in freshwater systems. Freshwater AOM-mediating microorganisms lack taxonomic identification and only little is known about metabolic adaptions to prevailing biogeochemical conditions. One of the first study sites providing information about AOM activity in freshwater sediment is Lake Ørn, a low-sulfate, iron-rich Danish lake. With the aim to identify freshwater AOM-mediating archaea, we incubated AOM-active anoxic, nitrate-free freshwater sediment from Lake Ørn with ${ }^{13} \mathrm{C}$-labeled methane $\left({ }^{13} \mathrm{C}_{\mathrm{CH}}\right)$ and ${ }^{13} \mathrm{C}$-labeled bicarbonate $\left({ }^{13} \mathrm{C}_{\mathrm{DIC}}\right)$ and followed the assimilation of ${ }^{13} \mathrm{C}$ into RNA by stable isotope probing. While AOM was active, ${ }^{13} \mathrm{C}_{\mathrm{CH} 4}$ and probably also ${ }^{13} \mathrm{C}_{\mathrm{DIC}}$ were incorporated into uncultured archaea of the Methanosarcinales-related cluster ANME-2d, whereas other known ANME lineages were not detected. This finding strongly suggests that ANME-2d archaea perform AOM coupled to sulfate and/or iron reduction and may have the capability of mixed assimilation of $\mathrm{CH}_{4}$ and DIC. ANME$2 \mathrm{~d}$ archaea may thus play an important role in controlling methane emissions from nitrate-depleted and low-sulfate freshwater systems.

Keywords: anaerobic oxidation of methane, ANME-2d, RNA stable isotope probing, freshwater sediment, low-sulfate iron-rich natural environment

\section{INTRODUCTION}

As a major sink of the greenhouse gas methane $\left(\mathrm{CH}_{4}\right)$, anaerobic oxidation of methane (AOM) is a significant regulator of the global methane cycle (Knittel and Boetius, 2009). Analysis of $16 \mathrm{~S}$ rRNA sequences links AOM to three distinct clusters of anaerobic methanotrophic archaea (ANaerobic MEthane oxidizers) named ANME-1, -2, and -3 that fall into the methanogenic orders Methanomicrobiales and Methanosarcinales (Knittel and Boetius, 2009) and in the class Methanomicrobia. The different ANME groups are related to each other with phylogenetic similarities as low as 75-92\% (based on 16S rRNA sequences; Knittel and Boetius, 2009) and inhabit a wide range of anoxic environments that differ markedly in their biogeochemical conditions. ANME strains were reported to be abundant in anoxic marine environments such as sulfatemethane-transition-zones (SMTZs), cold and hot seeps, the deep biosphere, and anoxic marine water columns, and were also, albeit rarely, detected in soils, aquifers and freshwater sediments (Knittel and Boetius, 2009 and references therein). 
All ANME strains oxidize methane using the reverse methanogenesis pathway (Hallam et al., 2004). Reducing equivalents resulting from anaerobic methane oxidation are transferred to either sulfate (Hinrichs et al., 1999; Boetius et al., 2000; Orphan et al., 2002), nitrate (Haroon et al., 2013), or iron and possibly manganese (Beal et al., 2009, 2011; Ettwig et al., 2016; Scheller et al., 2016). The transfer mechanisms of the reducing equivalents in ANME strains are not fully understood and different concepts have evolved according to the different electron acceptors. During sulfate-dependent AOM, ANME strains were often observed in consortia with sulfatereducing bacteria (Boetius et al., 2000) and currently three concepts allowing reducing equivalent transfer are discussed: (1) an obligate syntrophic process between the partners involving an interspecies electron carrier (e.g., Meulepas et al., 2010), (2) direct electron transfer by conductive pili (nanowires) providing cell-to-cell contact (McGlynn et al., 2015; Wegener et al., 2015) or (3) ANME carrying out both methane oxidation and sulfate reduction and excreting zero-valent sulfur compounds that are further disproportionated by the associated bacterial partners (Milucka et al., 2012). In contrast to this puzzling diversity of pathways, a nitrate-reducing ANME strain named 'Candidatus Methanoperedens nitroreducens' was shown to have the enzymatic capability to perform reverse methanogenesis while reducing nitrate on its own (Haroon et al., 2013). This strain is affiliated with the subgroup ANME-2d, also known as AAA (AOM-Associated Archaea), which was previously found in diverse environments with AOM activity but not conclusively linked to AOM (Knittel and Boetius, 2009). A coupling of AOM to the reduction of soluble ferric complexes was recently observed in an ANME-2 enrichment (Scheller et al., 2016) and a coupling to solid iron or manganese oxide reduction was suggested several times based on biogeochemical evidence (Beal et al., 2009; Sivan et al., 2011; Riedinger et al., 2014; Egger et al., 2015; Oni et al., 2015). Most recently, a strain closely related to 'Cand. M. nitroreducens' from a freshwater enrichment culture was shown to couple AOM to the reduction of soluble and nanoparticulate forms of ferric iron (Ettwig et al., 2016).

Our knowledge about AOM and the microorganisms involved derives almost exclusively from investigations of marine environments. In anoxic freshwater environments, sulfatedependent AOM has often been assumed to be insignificant due to low sulfate concentrations $\left(<1 \mathrm{mmol} \mathrm{L}^{-1}\right)$, but recent studies have shown that AOM can provide an efficient barrier to methane emission from lake sediment even at sulfate concentrations $<0.2$ mmol L ${ }^{-1}$ (Norði et al., 2013; Weber et al., 2016). In addition to the potential direct coupling of AOM to iron oxide reduction, AOM in low-sulfate environments could at least partially be coupled to sulfate reduction (Norði et al., 2013; Weber et al., 2016) with sulfate being recycled in the anoxic sediment by an iron-driven cryptic sulfur cycle (Riedinger et al., 2010; Holmkvist et al., 2011). Nitrate/nitrite-dependent AOM has also been documented in freshwater systems (Raghoebarsing et al., 2006; Deutzmann et al., 2014). There, nitrite-dependent AOM appears to be linked to the presence of bacteria of the NC10 clade (Ettwig et al., 2010; Deutzmann et al., 2014), while nitrate-dependent anaerobic methane oxidation might be carried out by the above-mentioned 'Cand. Methanoperedens nitroreducens,' although the distribution and role of this type of organism in natural systems remains to be investigated. Besides the ability to couple AOM to iron reduction shown in an enrichment culture (Ettwig et al., 2016), members of the ANME$2 \mathrm{~d}$ or AAA lineage containing 'Cand. M. nitroreducens' were suggested to convey sulfate-dependent AOM in the sediment of the alpine Lake Cadagno (Schubert et al., 2011) and a natural freshwater gas source (Timmers et al., 2016). The identity of microorganisms coupling freshwater AOM to sulfur cycling at low-sulfate conditions and metal oxide reduction, remains puzzling, but is of high importance for elucidating the pathways of methane oxidation in freshwater systems and understanding how the metabolic constraints and adaptions of microbes involved in AOM affect the global significance of the process.

In the present study, we aimed at revealing the taxonomic identity of anaerobic methane oxidizers in the low-sulfate, iron-rich sediment of Danish Lake Ørn, where AOM activity is well documented (Norði et al., 2013; Weber et al., 2016). We incubated sediment from the AOM-active zone of Lake Ørn with ${ }^{13} \mathrm{C}$-labeled methane $\left({ }^{13} \mathrm{C}_{\mathrm{CH}}\right)$ and ${ }^{13} \mathrm{C}$-labeled bicarbonate $\left({ }^{13} \mathrm{C}\right.$-Dissolved Inorganic Carbon: $\left.{ }^{13} \mathrm{C}_{\mathrm{DIC}}\right)$ and applied RNA stable isotope probing to identify archaea, which assimilated the ${ }^{13} \mathrm{C}$-labeled carbon sources. Additionally, we followed the turnover of sulfate and methane and determined sulfate reduction and anaerobic methane oxidation rates during incubations.

\section{MATERIALS AND METHODS}

\section{Study Site and Sediment Sampling}

Lake Ørn is a shallow mesotrophic Lake with iron-rich sediment located in Jutland, Denmark. It has an area of $0.43 \mathrm{~km}^{2}$, an average water depth of $4 \mathrm{~m}$ and a maximum water depth of $10.5 \mathrm{~m}$ (Skovgaard, 2004). The stream Funder Å supplies the lake with a high input of iron in form of ochre $\left(\sim 45 \mathrm{~g} \mathrm{Fe} \mathrm{m}^{-2}\right.$ year $^{-1}$ from 1989 to 2002; Skovgaard, 2004). Stratification is usually restricted to water depths greater than $\sim 5 \mathrm{~m}$ due to a high water flow and wind exposure.

Sediment sampling took place in April 2012 at the $4.5 \mathrm{~m}$ deep site near the center of the lake, for which the biogeochemistry was described previously (Norði et al., 2013; Weber et al., 2016). The water temperature was $8^{\circ} \mathrm{C}$ and the water column was oxygenated. Using a hand-operated Kajak sampler, three sediment cores (length $=30 \mathrm{~cm}$, inner diameter $=7.5 \mathrm{~cm}$ ) were retrieved for depth profiles of sulfate, methane, density/porosity and for RNA extraction. We dissected the cores obtained for depth profile characterization in $2 \mathrm{~cm}$ depth intervals under constant nitrogen flow within 2 days after sampling and subsampled for the different parameters as described below. To minimize a possible change of the biogeochemical depth profiles during storage, we air-bubbled the individual cores $\sim 2 \mathrm{~cm}$ above the sediment surface while keeping all cores in a tank filled with surface water from Lake Ørn. 
Additionally, 30 cores were taken for RNA stable isotope probing incubation experiments and further treated as described in the following section.

\section{RNA Stable Isotope Probing (RNA-SIP) Incubation Experiments}

RNA-SIP experiments were carried out in both core and slurry incubations. Both slurries and cores were subjected to five different treatments: addition of $(1){ }^{13} \mathrm{C}$-bicarbonate $\left({ }^{13} \mathrm{C}_{\mathrm{DIC}}\right)$, (2) ${ }^{12} \mathrm{C}$-bicarbonate $\left({ }^{12} \mathrm{C}_{\mathrm{DIC}}\right)$, (3) ${ }^{13} \mathrm{C}$-methane $\left({ }^{13} \mathrm{C}_{\mathrm{CH} 4}\right)$, (4) ${ }^{12} \mathrm{C}$-methane $\left({ }^{12} \mathrm{C}_{\mathrm{CH} 4}\right)$, and (5) no addition as control. For core incubations, 24 cores were transferred immediately after sampling to a $5^{\circ} \mathrm{C}$ tempered water tank (total volume $\sim 0.2 \mathrm{~m}^{3}$ ), which was filled with surface water from Lake Ørn. All cores were kept at these conditions for the entire incubation time and were individually and continuously oxygenated by gentle air bubbling $\sim 1 \mathrm{~cm}$ above the sediment. The core liners contained holes (diameter $=0.2 \mathrm{~cm}$ ), which were billowy winding around the liners (horizontal distance $=1 \mathrm{~cm}$, vertical distance $=2 \mathrm{~cm}$ ) and were double sealed with aquarium silicon (Dana Lim 579, ISO 11600) and poly-coated cloth tape (Tesa). ${ }^{13} \mathrm{C}_{\mathrm{CH} 4}$ and ${ }^{12} \mathrm{C}_{\mathrm{CH} 4}$ (both 99 atom-\%), ${ }^{13} \mathrm{C}_{\mathrm{DIC}}$ and ${ }^{12} \mathrm{C}_{\mathrm{DIC}}$ (both 99 atom-\%) were injected anoxically into the cores in $1 \mathrm{~cm}$ steps to $18 \mathrm{~cm}$ depth for methane and $25 \mathrm{~cm}$ depth for sodium bicarbonate, by means of a gas-tight syringe. Methane was added in increasing amounts with increasing sediment depth at days $1,4,7$, and 15 corresponding to final added concentrations of $\sim 40 \mu \mathrm{mol} \mathrm{L} \mathrm{L}^{-1}(0-5 \mathrm{~cm})$; $\sim 80 \mu \mathrm{mol} \mathrm{L}^{-1}(5-10 \mathrm{~cm}), \sim 120 \mu \mathrm{mol} \mathrm{L}-1(10-15 \mathrm{~cm})$, and $\sim 260 \mu \mathrm{mol} \mathrm{L}^{-1}(15-20 \mathrm{~cm})$, which corresponded to $\sim 50 \%$ of the initial methane concentrations and up to $\sim 80 \%$ of ${ }^{13} \mathrm{CH}_{4}$ at the last time point. ${ }^{13} \mathrm{C}_{\text {DIC }}$ and ${ }^{12} \mathrm{C}_{\text {DIC }}$ was supplied from an anoxic stock solution $\left(1 \mathrm{~mol} \mathrm{~L}^{-1}\right)$ at days 1 and 14 to added concentrations of $\sim 1.4 \mathrm{mmol} \mathrm{L}^{-1}(0-5 \mathrm{~cm}), \sim 1.7 \mathrm{mmol} \mathrm{L}^{-1}(5-$ $15 \mathrm{~cm})$, and $\sim 2 \mathrm{mmol} \mathrm{L}^{-1}(15-25 \mathrm{~cm}) . \delta^{13} \mathrm{C}_{\text {DIC }}$ measurements confirmed a range of $\sim 7$ to $\sim 25$ atom- $\%{ }^{13} \mathrm{C}_{\text {DIC }}$ in the DIC pool of the entire depth, whereas in the layer $10-15 \mathrm{~cm},{ }^{13} \mathrm{C}_{\text {DIC }}$ was in a range of $\sim 13$ to 21 atom- $\%$.

The cores were incubated for 30 days in total and sampled after $3,6,14$, and 30 days. For sampling, one control core, one ${ }^{12} \mathrm{C}$ core, and one ${ }^{13} \mathrm{C}$ core were sliced under constant nitrogen flow into $5 \mathrm{~cm}$ intervals to a sampling depth of $25 \mathrm{~cm}$. At each time point, subsamples were taken to determine porosity, concentrations of sulfate and methane, to quantify rates of microbial sulfate reduction (SR) and anaerobic oxidation of methane (AOM), and for RNA extraction for RNA-SIP analysis.

For slurry SIP incubations, sediment from the depth interval 10-15 cm was extracted from six sediment cores under constant nitrogen flow, transferred into a glass bottle (Schott) and sealed with a butyl rubber stopper. The bottle was transferred into a nitrogen-filled glove bag and sediment was mixed 1:1 with $\mathrm{N}_{2}$-purged medium (50 $\mu \mathrm{mol} \mathrm{L}{ }^{-1} \mathrm{Na}_{2} \mathrm{SO}_{4}$ and $3 \mathrm{mmol} \mathrm{L}{ }^{-1}$ $\mathrm{NaHCO}_{3}$ ). Slurry was then distributed into 20 serum bottles $(60 \mathrm{~mL})$ that were closed with butyl rubber stoppers (kept under helium atmosphere prior to usage; De Brabandere et al., 2012) without headspace. By means of a gas-tight syringe, ${ }^{12} \mathrm{C}_{\mathrm{CH} 4}$ was added at day 0 to all bottles through the butyl rubber stopper to a final concentration of $120 \mu \mathrm{mol} \mathrm{L}^{-1}$, simulating concentrations similar to the core incubations. One-third of the incubations received additional $60 \mu \mathrm{mol} \mathrm{L}^{-1}{ }^{12} \mathrm{C}_{\mathrm{CH} 4}$ and one-third received additional $60 \mu \mathrm{mol} \mathrm{L}-1{ }^{13} \mathrm{C}_{\mathrm{CH} 4}$, which raised the total methane concentration to $180 \mu \mathrm{mol} \mathrm{L} \mathrm{L}^{-1}$ in these incubations. In the remaining $1 / 3$ of the slurries, no further methane was added as they were used as controls. At days 3, 6, and 27 additional $60 \mu \mathrm{mol} \mathrm{L}-1{ }^{12} \mathrm{C}_{\mathrm{CH} 4}$ or ${ }^{13} \mathrm{C}_{\mathrm{CH} 4}$ was added to the ${ }^{12} \mathrm{C}_{\mathrm{CH} 4}$ and ${ }^{13} \mathrm{C}_{\mathrm{CH} 4}$ incubations, respectively. For DIC slurry experiments, $1.3 \mathrm{mmol} \mathrm{L}{ }^{-1}{ }^{12} \mathrm{C}_{\text {DIC }}$ or ${ }^{13} \mathrm{C}_{\text {DIC }}$ was added to ${ }^{12} \mathrm{C}_{\mathrm{DIC}}$ and ${ }^{13} \mathrm{C}_{\mathrm{DIC}}$ incubations, respectively, at days 1 and $27 . \delta^{13} \mathrm{C}_{\mathrm{DIC}}$ measurements confirmed a range of $\sim 15$ to $\sim 25{ }^{13} \mathrm{C}_{\text {DIC }}$ atom$\%$ in the DIC pool. All bottles were stored in darkness at $5^{\circ} \mathrm{C}$ and carefully inverted every few days. In total we had 20 slurries, which were successively sampled after 3, 6, 27, and 72 days. For sampling, one bottle from each treatment was opened in a nitrogen-flushed glove bag and sampled for measurements of the same biogeochemical, molecular and rate measurements as described for the cores.

\section{Gaseous, Solid, and Porewater Parameters}

All cores and slurries were processed under constant nitrogen flow and at $4^{\circ} \mathrm{C}$ and subsamples were taken either by cut-off syringes or a spatula.

For porewater analysis, $15 \mathrm{~mL}$ centrifugation vials were filled completely, capped, centrifuged at $4^{\circ} \mathrm{C}$ at $4000 \mathrm{~g}$ for $10 \mathrm{~min}$ (Centrifuge 5810; Eppendorf) and the supernatant was filtered anoxically (glove bag filled with nitrogen) through a syringe filter (pore size $=0.22 \mu \mathrm{m}$; syringe, needle and filter flushed and stored in helium prior to usage). For analysis of sulfate, $1 \mathrm{ml}$ porewater each was mixed with $20 \mu \mathrm{L} 20 \%$ zinc acetate $(\mathrm{ZnAc})$ and stored at $-20^{\circ} \mathrm{C}$. Sulfate concentrations were quantified via ion chromatography (Dionex ICS-1500, detector: DS6 Heated Conductivity Cell), using ultrapure water ("type 1") containing $4.5 \mathrm{mmol} \mathrm{L}{ }^{-1} \mathrm{Na}_{2} \mathrm{CO}_{3}$ and $1.4 \mathrm{mmol}$ $\mathrm{L}^{-1} \mathrm{NaHCO}_{3}$, as eluent. The detection limit for sulfate was $1 \mu \mathrm{mol} \mathrm{L}{ }^{-1}$. For DIC concentration and $\delta^{13} \mathrm{C}$ measurements, porewater was stored in $1.8 \mathrm{ml}$ septum vials on $10 \mu \mathrm{L}$ saturated mercury chloride $\left(\mathrm{HgCl}_{2}\right)$ at $4^{\circ} \mathrm{C}$. For analysis $300 \mu \mathrm{L}$ sample was transferred into a $12 \mathrm{~mL}$ acid washed and helium-flushed Exetainer (Labco, High Wycombe, UK) and $50 \mu \mathrm{L}$ of $85 \%$ phosphoric acid was added to drive $\mathrm{CO}_{2}$ into the headspace over an equilibration phase of $15 \mathrm{~h}$. The ${ }^{13} \mathrm{C}$ atom-\% values were determined by IRMS, using the standards NBS 18-Calcite and IAEA-LSVEC Lithium Carbonate and an in-house bicarbonate standard (average standard deviation between samples $=0.1 \%$ ).

To determine methane concentrations, $2 \mathrm{~cm}^{3}$ of sediment or slurry was subsampled directly into a $20 \mathrm{~mL}$ serum vial, prefilled with $5 \mathrm{~mL} 2.5 \%$ sodium hydroxide $(\mathrm{NaOH})$ that was closed and shaken immediately and stored upside down for at least $24 \mathrm{~h}$ to drive the methane into the headspace. Methane concentrations were quantified by injecting $50-100 \mu \mathrm{L}$ of the headspace into a gas chromatograph with an FID detector (Perkin Elmer). The porosity/density of sediment or slurry was determined by subsampling $1 \mathrm{~cm}^{3}$ sediment or slurry with a cut-off pipette tip into a pre-weighted centrifugation vial and the 
water content/porosity from the weight loss from after drying at $90^{\circ} \mathrm{C}$ for $48 \mathrm{~h}$.

\section{Rates of Dissimilatory Sulfate Reduction (SR) and Anaerobic Oxidation of Methane (AOM)}

For SR and AOM rates, $5 \mathrm{~cm}^{3}$ sediment or slurry was filled into glass tubes in triplicates or duplicates, respectively, closed with plunger and septum (stored under helium 6 weeks prior to sampling) and pre-incubated for $1 \mathrm{~h}$ before injection of radiotracers (Jørgensen, 1978).

For SR rates, $20 \mu \mathrm{L}$ carrier-free ${ }^{35} \mathrm{SO}_{4}{ }^{2-}$ tracer $(100 \mathrm{kBq})$ sample ${ }^{-1}$ was injected through the septum, the tubes inverted and the samples incubated at $5^{\circ} \mathrm{C}$ in darkness for $24 \mathrm{~h}$. The incubations were stopped by transferring the samples into $10 \mathrm{~mL}$ of $20 \%$ ZnAc. Controls ("killed controls") were taken in parallel, in which sediment/slurry was transferred into $10 \mathrm{~mL}$ of $20 \%$ ZnAc after $24 \mathrm{~h}$ and thereafter tracer was added. All samples and controls were frozen immediately and stored at $-20^{\circ} \mathrm{C}$ until analysis. After thawing, supernatants were separated from solid phases by centrifuging the samples at $500 \mathrm{~g}$ for $5 \mathrm{~min}$ and decanting. Supernatants were subsampled for determination of ${ }^{35} \mathrm{~S}$ in sulfate and reduced sulfur compounds were extracted via the cold chromium distillation for ${ }^{35} \mathrm{~S}$ determination (Kallmeyer et al., 2004; Røy et al., 2014).

For AOM rates, ${ }^{14} \mathrm{CH}_{4}$ (dissolved in water; $20 \mu \mathrm{l}$; $\sim 0.5 \mathrm{kBq}$; supplied from American Radiolabeled Chemicals, cleaned with hopcalite and sodium hydroxide) was injected through the septum into the sediment or slurry, the tubes inverted and samples incubated at $5^{\circ} \mathrm{C}$ in darkness for $20 \mathrm{~h}$. In order to stop incubations the samples were transferred into glass vials prefilled with $15 \mathrm{ml}$ 2.5\% (w/v) sodium hydroxide and immediately closed with butyl rubber stoppers, shaken and stored upside down. Methane concentrations were determined as described above and activities of ${ }^{14} \mathrm{CH}_{4}$ and ${ }^{14} \mathrm{CO}_{2}$ were quantified (Treude et al., 2005), using phenylethylamine and sodium hydroxide (1:1) as $\mathrm{CO}_{2}$ trap. Duplicates of "killed controls" were taken with each time point, in which tracer was injected after termination of microbial activity.

Radioactivity was measured on a QuantaSmart-4.00 Scintillation counter (count time: $10 \mathrm{~min}$; coincidence time: $18 \mathrm{nsec}$; delay before burst: $75 \mathrm{nsec}$ ). The detection limits for the SR and $\mathrm{AOM}$ rate measurements were determined by subtracting the mean plus three times the standard deviation of the killed controls from the product pools, ${ }^{35} \mathrm{~S}$ sulfides and ${ }^{14} \mathrm{CO}_{2}$, respectively.

\section{Subsampling, Extraction, and Quantification of RNA}

For each time point and incubation treatment, $\sim 5 \mathrm{~cm}^{3}$ of sediment or slurry was frozen immediately after sampling in liquid nitrogen and stored at $-80^{\circ} \mathrm{C}$ until further processing. RNA was extracted using the PowerSoil Total RNA Isolation Kit (MoBio) and further purified using the AllPrep DNA/RNA Mini Kit (Quiagen). RNA concentrations were quantified with the Quant-iT-RiboGreen RNA Assay Kit (Life Technologies).

\section{Caesium Trifluoroacetate (CsTFA) Density Gradient Ultracentrifugation and Fractionation}

Caesium trifluoroacetate density gradient ultracentrifugation was applied as described previously (Whiteley et al., 2007). Briefly, extracted and purified RNA ( $\sim 600 \mathrm{ng}$ in $24 \mu \mathrm{L}$ nuclease-free ultrapure water) was mixed with a carefully adjusted density $\left(1.8 \pm 0.04 \mathrm{~g} \mathrm{~mL}^{-1}\right)$ gradient medium containing CsTFA (4.64 $\mathrm{mL}$ sample $\left.{ }^{-1}\right)$, nuclease-free ultrapure water $(0.936 \mathrm{~mL}$ sample $\left.\mathrm{e}^{-1}\right)$ and formamide $\left(0.198 \mathrm{~mL}\right.$ sample $\left.{ }^{-1}\right)$. From this mixture, $5.1 \mathrm{~mL}$ was transferred into ultracentrifugation tubes (Quick-Seal, $5.2 \mathrm{~mL}, 13 \times 51 \mathrm{~mm}$; polyallomer, Beckmann Coulter) and closed by heat sealing. The tubes were centrifuged for $72 \mathrm{~h}$ (Beckmann Ultracentrifuge Optima XPN 80k RPM; Vertical rotor VTi 65,2 ) at $38400 \mathrm{rpm}, 20^{\circ} \mathrm{C}$ with maximum acceleration and deceleration. After ultracentrifugation, the gradient was fractionated into 20 fractions by driving the gradient out at the bottom of the tube at a controlled constant

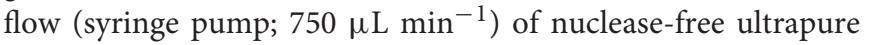
water into the top of the tube. From each fraction, $60 \mu \mathrm{L}$ was used for density measurement (Refractometer DR 30195, Krüss) and weight determination (microbalance Satorius Extend) and the rest was precipitated with two volumes of ice-cold isopropanol (molecular range, >99\%) and $4 \mu \mathrm{L}$ glycogen $\left(5 \mathrm{mg} \mathrm{mL}^{-1}\right)$ for at least $30 \mathrm{~min}$ at $-20^{\circ} \mathrm{C}$. After precipitation, the fractions were centrifuged for $30 \mathrm{~min}$ at $4^{\circ} \mathrm{C}(139000 \mathrm{rpm})$ and the supernatant decanted. The residual pellet was washed with $500 \mu \mathrm{L} 70 \%$ ethanol (molecular range, $>99 \%$ ) and centrifuged again as before. The supernatant was removed and the pellet resuspended in $30 \mu \mathrm{L}$ nuclease-free ultrapure water. The RNA concentrations of all fractions were determined using the Quant-iT-RiboGreen RNA Assay Kit (Life Technologies).

For determining the ${ }^{13} \mathrm{C}$-enriched fractions in the CsTFA sample gradients, we aligned a ${ }^{13} \mathrm{C}$-enriched Escherichia coli gradient (" ${ }^{13} \mathrm{C}_{\text {acetate }}$ E. coli standard", Supplementary Figure S4) and compared the locations of the ${ }^{13} \mathrm{C}$-peaks. To obtain the ${ }^{13} \mathrm{C}_{\text {acetate }} E$. coli standard, we incubated $E$. coli over 4 days in minimal medium $(\mathrm{pH}=7)$ containing sodium hydrogen phosphate $\left(\mathrm{Na}_{2} \mathrm{HPO}_{4}, 6 \mathrm{~g} \mathrm{~L}^{-1}\right)$, potassium dihydrogen phosphate $\left(\mathrm{KH}_{2} \mathrm{PO}_{4}, 3 \mathrm{~g} \mathrm{~L}^{-1}\right)$, ammonium chloride $\left(\mathrm{NH}_{4} \mathrm{Cl}, 1 \mathrm{~g}\right.$ $\left.\mathrm{L}^{-1}\right)$, sodium chloride ( $\left.\mathrm{NaCL}, 0.5 \mathrm{~g} \mathrm{~L}^{-1}\right)$, magnesium sulfate $\left(\mathrm{MgSO}_{4}, 0.12 \mathrm{~g} \mathrm{~L}^{-1}\right)$, calcium chloride $\left(\mathrm{CaCl}_{2}, 0.01 \mathrm{~g} \mathrm{~L}^{-1}\right)$ and ${ }^{13} \mathrm{C}$-sodium acetate $\left({ }^{13} \mathrm{CH}_{3}{ }^{13} \mathrm{CO}_{2} \mathrm{Na}, 99\right.$ atom-\%, $\left.0.25 \mathrm{~g} \mathrm{~L}^{-1}\right)$ as sole carbon source. After incubation, RNA was extracted and purified, CsTFA density gradient centrifugation was carried out and RNA concentrations were quantified for 20 fractions as described for the sediment/slurry samples.

\section{Transcription, PCR Amplification, Terminal Restriction Fragment Length Polymorphism (T-RFLP) Analysis and Cloning}

RNA of selected fractions was transcribed into complementary DNA (cDNA) using the Sensiscript RT Kit (Quiagen) with 
the primer U1492R (5'-GGYTACCTTGTTACGACTT-3'), following the manufacturer's instructions.

For PCR amplification, for each sample a $50 \mu \mathrm{L}$ PCR reaction mix containing $\sim 10 \mathrm{ng}$ template cDNA, 20 pmol of each primer (A958R: 5' -YCCGGCGTTGAMTCCAATT-3' and A20F 5'-TCYGGTTGATCCTGCCRG-3'), 1.25 U Taq polymerase (Fermentas), $40 \mathrm{nmol}$ deoxynucleotides and $125 \mathrm{nmol} \mathrm{MgCl}_{2}$ in $1 \mathrm{x}$ Taq reaction buffer (Fermentas) was prepared on ice and cycled in the PCR cycler with the following program: $2 \mathrm{~min}$ at $95^{\circ} \mathrm{C}$, followed by 39 cycles of $1 \mathrm{~min}$ at $95^{\circ} \mathrm{C}, 2 \mathrm{~min}$ at $55^{\circ} \mathrm{C}, 4 \mathrm{~min}$ at $72^{\circ} \mathrm{C}, 4 \mathrm{~min}$ and finally $10 \mathrm{~min}$ at $72^{\circ} \mathrm{C}$.

For T-RFLP analyses, cDNA was amplified by PCR as described above with the primer pair A958R and A20F-FAM (5'-TCYGGTTGATCCTGCCRG-3'). Thereafter, $10 \mu \mathrm{L}$ of each amplicon DNA sample was digested with $5 \mathrm{U} B s u \mathrm{RI}$ (HaeIII) restriction enzyme (Fermentas) at $37^{\circ} \mathrm{C}$ for $8 \mathrm{~h}$ and thereafter purified with GeneJet PCR purification Kit (Fermentas Life Technologies). Terminal restriction fragment length polymorphism (T-RFLP) analysis was performed with an Applied Biosystems ABI3730XL sequencer (capillary electrophoresis) at Uppsala Genome Center (Sweden).

16S rRNA clone libraries were carried out for one representative gradient fraction of the ${ }^{13} \mathrm{C}$ and ${ }^{12} \mathrm{C}$ peak, each from the successful ${ }^{13} \mathrm{C}_{\mathrm{CH} 4}$ and ${ }^{13} \mathrm{C}_{\mathrm{DIC}}$ incubation and from the $\mathrm{T}_{0}$ slurry and $\mathrm{T}_{1}$ core control. Hereby, $7 \mu \mathrm{L}$ cDNA amplicon of each sample was blunted and ligated with a pJET 1.2/blunt Cloning vector using the CloneJET PCR Cloning Kit (Thermo-Scientific) and transformed into chemically competent E. coli cells (One Shot TOP 10F' from Invitrogen) according to the manufacturer's instructions. The cells were spread on prewarmed LB plates containing ampicillin and incubated overnight at $37^{\circ} \mathrm{C}$. Thereafter, clones were screened using a colony PCR with primers PJF (5'-CGACTCACTATAGGGAGAGCGGC-3') and pJR ( $5^{\prime}-$ AAGAACATCGATTTTCCATGGCAG- $\left.3^{\prime}\right)$. The archaeal clones were sent to Macrogen Europe (Netherlands) for sequencing.

\section{Treatment of T-RFLP Data and Phylogenetic Analysis of Sequences}

Accurate T-RF sizes were determined using Peak ScannerTM (Applied Biosystems) on the obtained T-RFLP data from Uppsala Genome Center. Thereafter, the online source T-RFLP analysis Expedited $^{1}$ was used for noise filtration (noise filtration factor 1.0; peak area) and T-RF binning. All OTUs, which had a relative abundance $<1 \%$ were removed manually afterwards. Sequences obtained from the $16 \mathrm{~S}$ rRNA libraries were scanned using the program "4 peaks" and low quality ends, vector and primer sequences were removed manually. Chimeras were detected by the online tool Bellerophon (Huber et al., 2004), evaluated manually and removed. Sequences, which passed the quality control, were imported into the SSU Reference 115 SILVA database for phylogenetic reconstructions (Pruesse et al., 2007) using the ARB software package (Ludwig et al., 2004). All 208 sequences have been deposited at GenBank under the accession numbers KX463063 - KX463269 (Supplementary Table S3).

${ }^{1}$ http://trex.biohpc.org/

\section{RESULTS}

\section{Sediment Biogeochemistry In Situ and in Incubations}

The anoxic sediment column contained sulfate until a depth of $\sim 15 \mathrm{~cm}$ with a maximum concentration of $\sim 200 \mu \mathrm{mol} \mathrm{L}^{-1}$ at the surface (Figure 1B), similar as previously reported (Norði et al., 2013; Weber et al., 2016). The methane content increased with depth and reached concentrations of $\sim 900 \mu \mathrm{mol} \mathrm{L}^{-1}$ (Figure 1A). AOM activity was indicated at $5-15 \mathrm{~cm}$ depth by the concave shape of the methane profile, and thereby occurred within the depth interval of sulfate consumption and iron reduction, as indicated by the distributions of sulfate and soluble $\mathrm{Fe}^{2+}$ (Figure 1), and consistent with previous direct rate measurements using radiotracer incubations and with analyses of particulate iron speciation (Norði et al., 2013; Weber et al., 2016).

Sediment and slurries were incubated with ${ }^{13} \mathrm{C}_{\mathrm{CH} 4}$ or ${ }^{13} \mathrm{C}_{\mathrm{DIC}}$, their ${ }^{12} \mathrm{C}$ analogs or without addition (controls) for maximum 30 and 72 days, respectively. As described in more detail below, ${ }^{13} \mathrm{C}$-labeling of RNA was achieved in the ${ }^{13} \mathrm{C}_{\mathrm{CH} 4}$ core and ${ }^{13} \mathrm{C}_{\mathrm{DIC}}$ slurry incubations. We therefore focus on the biogeochemical results from these incubations here (Figures 2, 3), while the results of the ${ }^{13} \mathrm{C}_{\mathrm{DIC}}$ core and ${ }^{13} \mathrm{C}_{\mathrm{CH} 4}$ slurry incubations are displayed in Supplementary Figures S1, S2. At incubation start, sulfate concentrations at $10-15 \mathrm{~cm}$ were higher in the slurries $\left(\sim 37 \mu \mathrm{mol} \mathrm{L}{ }^{-1}\right)$ than in the cores $\left(10-15 \mu \mathrm{mol} \mathrm{L}{ }^{-1}\right)$, due to the addition of sulfate-containing medium (Figures $2 B, 3 \mathbf{B}$ and Supplementary Figures S1B, S2B). All slurry incubations showed a decrease in sulfate concentrations in all treatments with a mean rate of $\sim 0.3 \pm 0.2 \mu \mathrm{mol} \mathrm{L} \mathrm{L}^{-1} \mathrm{~d}^{-1}$. In the core incubations, sulfate concentrations remained at $10-15 \mu \mathrm{mol} \mathrm{L}^{-1}$ or tended to decrease but only dropped below detection at the last time point in the ${ }^{12} \mathrm{C}_{\text {DIC }}$ and ${ }^{13} \mathrm{C}_{\text {DIC }}$ incubations. Methane concentrations increased in the control slurry incubation with $\sim 4 \pm 3 \mu \mathrm{mol} \mathrm{L}^{-1}$ $\mathrm{d}^{-1}$, indicating net methanogenesis. A similar rate of increase in the control core incubation together with the decrease in sulfate indicated an upward shift of the redox zonation during the incubation while the increase in methane in the ${ }^{12} \mathrm{C}_{\mathrm{CH} 4}$ and ${ }^{13} \mathrm{C}_{\mathrm{CH} 4}$ cores and slurries reflected the repeated injection of methane to these. In the ${ }^{12} \mathrm{C}_{\mathrm{DIC}}$ - and ${ }^{13} \mathrm{C}_{\mathrm{DIC}}$-amended core and slurry incubations, methane concentrations did not show a clear trend over time. Radiotracer incubations in control and ${ }^{13} \mathrm{C}_{\mathrm{CH}} 4$ incubations confirmed SR and AOM activity in cores and slurries at all time points (Figures 2D,E, 3D,E and Supplementary Figures S2D,E; see also additional discussion in Supplementary). On average, SR showed rates of $11 \pm 3 \mu \mathrm{mol} \mathrm{L} \mathrm{L}^{-1} \mathrm{~d}^{-1}$ and $12 \pm 5 \mu \mathrm{mol} \mathrm{L}{ }^{-1} \mathrm{~d}^{-1}$ in control and ${ }^{13} \mathrm{C}_{\mathrm{CH} 4}$-amended cores, respectively, and average $A O M$ rates of $3 \pm 1 \mu \mathrm{mol} \mathrm{L}^{-1} \mathrm{~d}^{-1}$ in both (Figures 2D,E). In slurries, SR and AOM rates were similar to the rates in the core incubations, with an average SR rate of $9 \pm 4 \mu \mathrm{mol} \mathrm{L}-1 \mathrm{~d}^{-1}$ in both control and ${ }^{13} \mathrm{C}_{\mathrm{CH} 4}{ }^{-}$ amended slurries and $\mathrm{AOM}$ rates of $5 \pm 3$ and $4 \pm 2 \mu \mathrm{mol}$ $\mathrm{L}^{-1} \mathrm{~d}^{-1}$ in control and ${ }^{13} \mathrm{C}_{\mathrm{CH} 4}$-amended slurries, respectively (Figures 3D,E).

As the addition of ${ }^{13} \mathrm{C}_{\mathrm{DIC}},{ }^{12} \mathrm{C}_{\mathrm{DIC}},{ }^{13} \mathrm{C}_{\mathrm{CH} 4}$ or ${ }^{12} \mathrm{C}_{\mathrm{CH} 4}$ did not impact the biogeochemistry of the incubations nor SR and AOM 

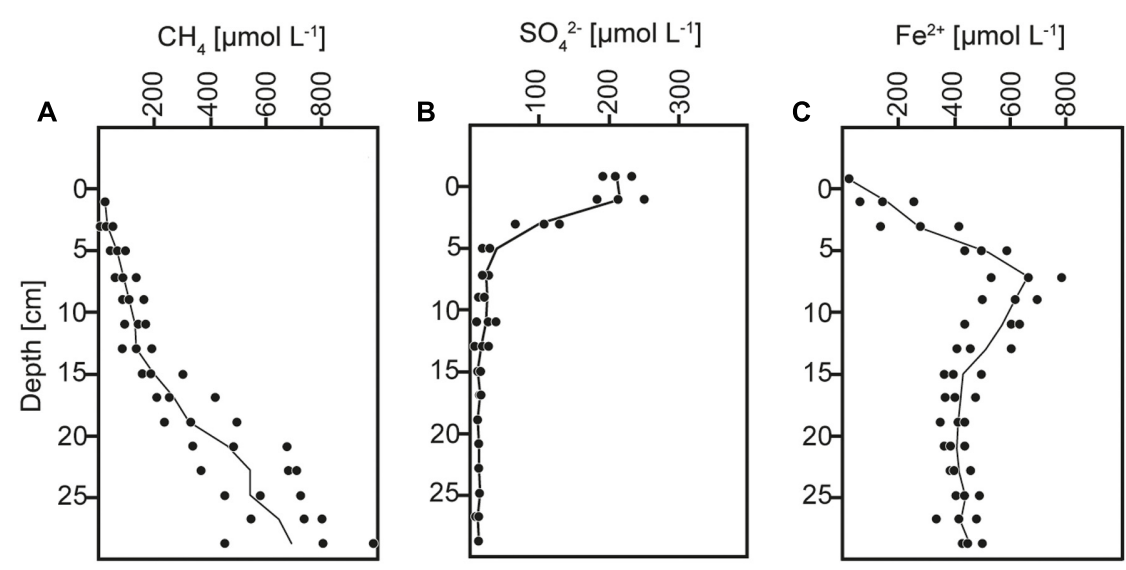

FIGURE 1 | Concentration depth profiles of (A) methane $\left(\mathrm{CH}_{4}\right)$, (B) sulfate $\left(\mathrm{SO}_{4}{ }^{2-}\right)$, and (C) dissolved iron $\left(\mathrm{Fe}^{2+}\right)$.
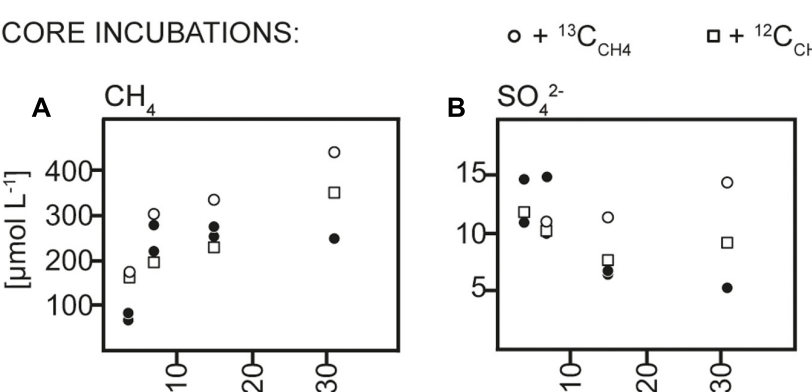

\section{- control}
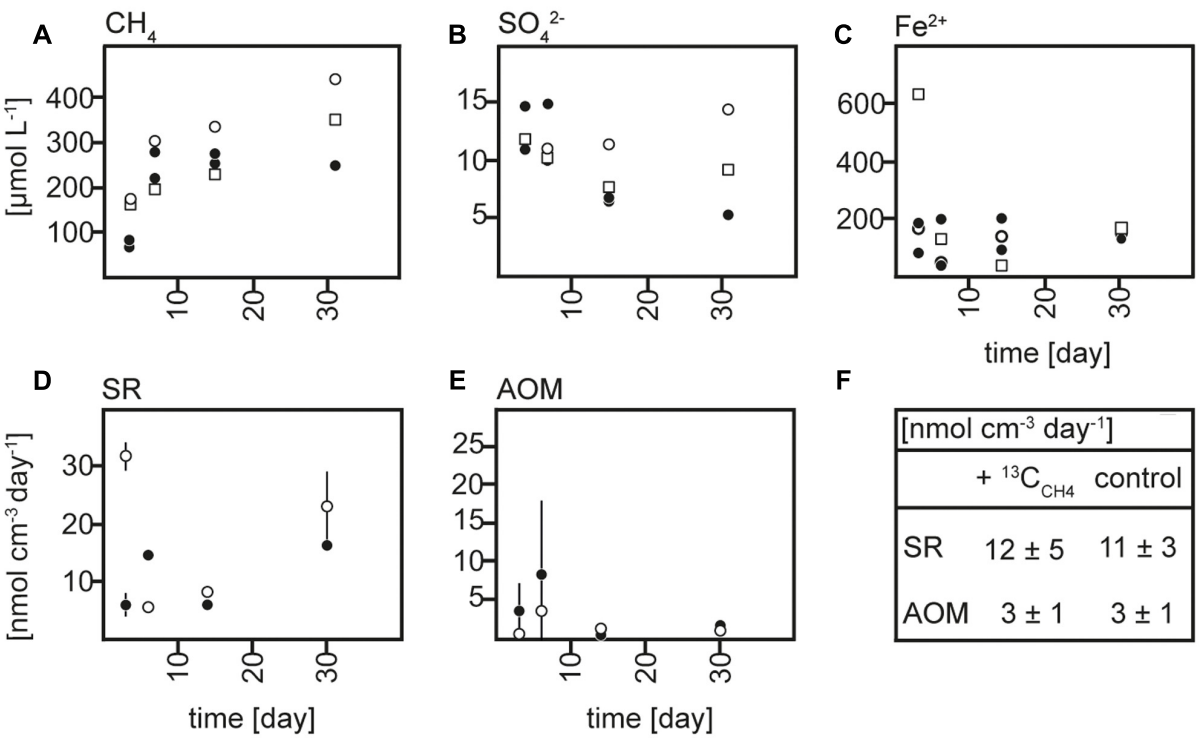

FIGURE 2 | Concentrations over time of (A) methane $\left(\mathrm{CH}_{4}\right)$, (B) sulfate $\left(\mathrm{SO}_{4}{ }^{2-}\right)$, and (C) dissolved iron $\left(\mathrm{Fe}^{2+}\right)$, rates over time of (D) sulfate reduction (SR) and (E) anaerobic methane oxidation (AOM) in ${ }^{13} \mathrm{C}_{\mathrm{CH} 4},{ }^{12} \mathrm{C}_{\mathrm{CH}}$ and control core incubations and $(\mathbf{F})$ average rates of $\mathrm{SR}$ and $\mathrm{AOM}$ in ${ }^{13} \mathrm{C}_{\mathrm{CH} 4}$ and control core incubations.

rates substantially, we rule out a major impact on the microbial community due to amendments in comparison to the control incubations. Therefore, we interpret the control, ${ }^{12} \mathrm{C}_{\mathrm{CH} 4}$ and ${ }^{13} \mathrm{C}_{\mathrm{CH} 4}$ core incubations and the control, ${ }^{12} \mathrm{C}_{\mathrm{DIC}},{ }^{13} \mathrm{C}_{\mathrm{DIC}}$ slurry incubations, respectively, as biogeochemical replicates.

\section{Taxonomic Identification of Archaea}

The initial composition of the active part of the archaeal community was assessed by two 16S rRNA clone libraries originating from the slurry and from a core before ${ }^{13} \mathrm{C}$ addition. In total, 76 clones were retrieved, from which $\sim 40 \%$ were assigned to the phylum Euryarchaeota, $\sim 8 \%$ to Miscellaneous Euryarchaeotic Group and Aenigmarchaeota and $\sim 52 \%$ to the phylum Crenarchaeota (Table 1 and Supplementary
Table S1). Within the Euryarchaeota, the two largest groups were Thermoplasmatales with 19 clones and the Methanosarcinales cluster AMNE-2d with nine clones, whereas Methanosaeta showed minor contributions. Almost all sequences that fell into the phylum Crenarchaeota were assigned to Miscellaneous Crenarchaeotic Group.

Sufficient amounts of ${ }^{13} \mathrm{C}$-labeled RNA for clear ${ }^{13} \mathrm{C}$ - and ${ }^{12} \mathrm{C}$ fraction separation during CsTFA centrifugation and subsequent reverse transcription were obtained after 30 days in the ${ }^{13} \mathrm{C}_{\mathrm{CH} 4}$ core incubation and after 73 days in the ${ }^{13} C_{\text {DIC }}$ slurry incubation, while no RNA was detected in, and no cDNA could be obtained by reverse transcription of the high density gradient fractions sampled earlier during the incubations. The cDNA generated from the ${ }^{12} \mathrm{C}$ and ${ }^{13} \mathrm{C}$ fractions of the density gradient was 
SLURRY INCUBATIONS:
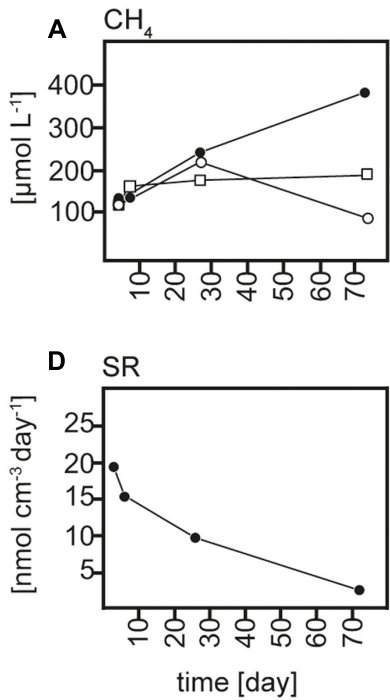

$\circ+{ }^{13} \mathrm{C}_{\mathrm{DIC}}$

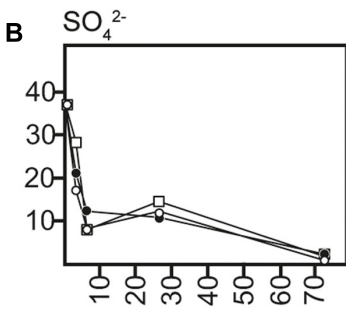

E

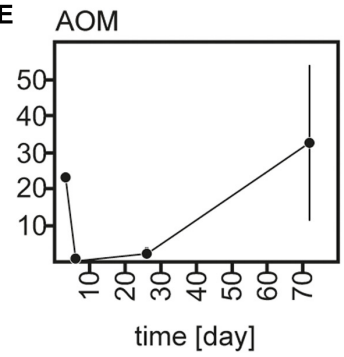

- control

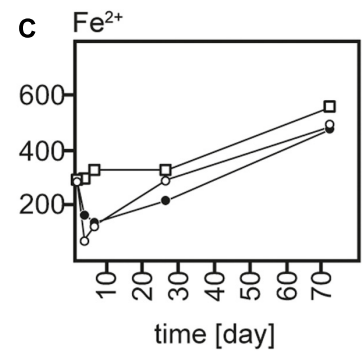

$\mathbf{F}$

\begin{tabular}{|lll|}
\hline \multicolumn{3}{|c|}{$\mathrm{nmol} \mathrm{cm}^{-3}$ day } \\
\hline & ${ }^{13} \mathrm{C}_{\mathrm{DIC}}$ & control \\
\hline $\mathrm{SR}$ & n.a. & $9 \pm 4$ \\
AOM & n.a. & $5 \pm 3$ \\
\hline
\end{tabular}

FIGURE 3 | Concentrations over time of (A) methane $\left(\mathrm{CH}_{4}\right)$, (B) sulfate $\left(\mathrm{SO}_{4}{ }^{2-}\right)$, and (C) dissolved iron $\left(\mathrm{Fe}^{2+}\right)$, rates over time of (D) sulfate reduction (SR) and (E) anaerobic methane oxidation (AOM) in ${ }^{13} \mathrm{C}_{\mathrm{DIC}},{ }^{12} \mathrm{C}_{\mathrm{DIC}}$ and control slurry incubations and $\mathbf{( F )}$ average rates of SR and $\mathrm{AOM}$ in ${ }^{13} \mathrm{C}_{\mathrm{DIC}}$ and control slurry incubations; n.a., not analyzed.

TABLE 1 | Taxonomic affiliation and number of sequences obtained from 16S rRNA clone libraries at incubation start ( $\left.T_{0}\right)$ and for one representative sample of ${ }^{13} \mathrm{C}_{\mathrm{CH} 4}$ and ${ }^{13} \mathrm{C}_{\mathrm{DIC}}$ incubations, each from the ${ }^{13} \mathrm{C}$ fraction and the ${ }^{12} \mathrm{C}$ fraction of the same CsTFA gradients.

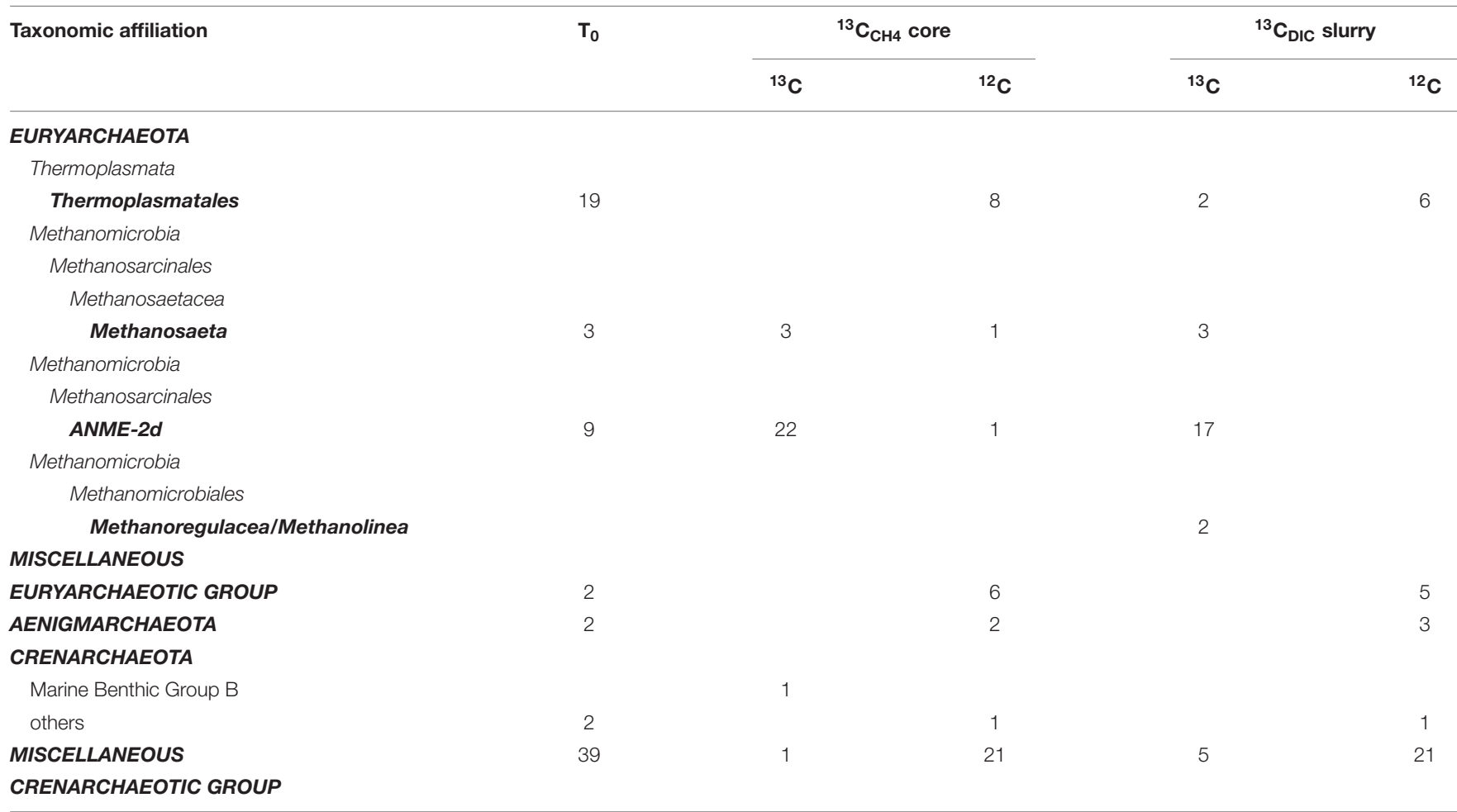

amplified and resulted in archaeal products that were used to construct 16S rRNA clone libraries and perform T-RFLP analysis.

The archaeal 16S rRNA clone library constructed from the ${ }^{13} \mathrm{C}$ fraction of the ${ }^{13} \mathrm{C}_{\mathrm{CH} 4}$ incubation was strongly enriched in sequences affiliated closely to ANME-2d, which made up $82 \%$ of the total (22 of 27; Figure 4, Table 1 and Supplementary Table S1). Of the remainder, three sequences were closely related to the aceticlastic methanogen Methanosaeta concilii that 


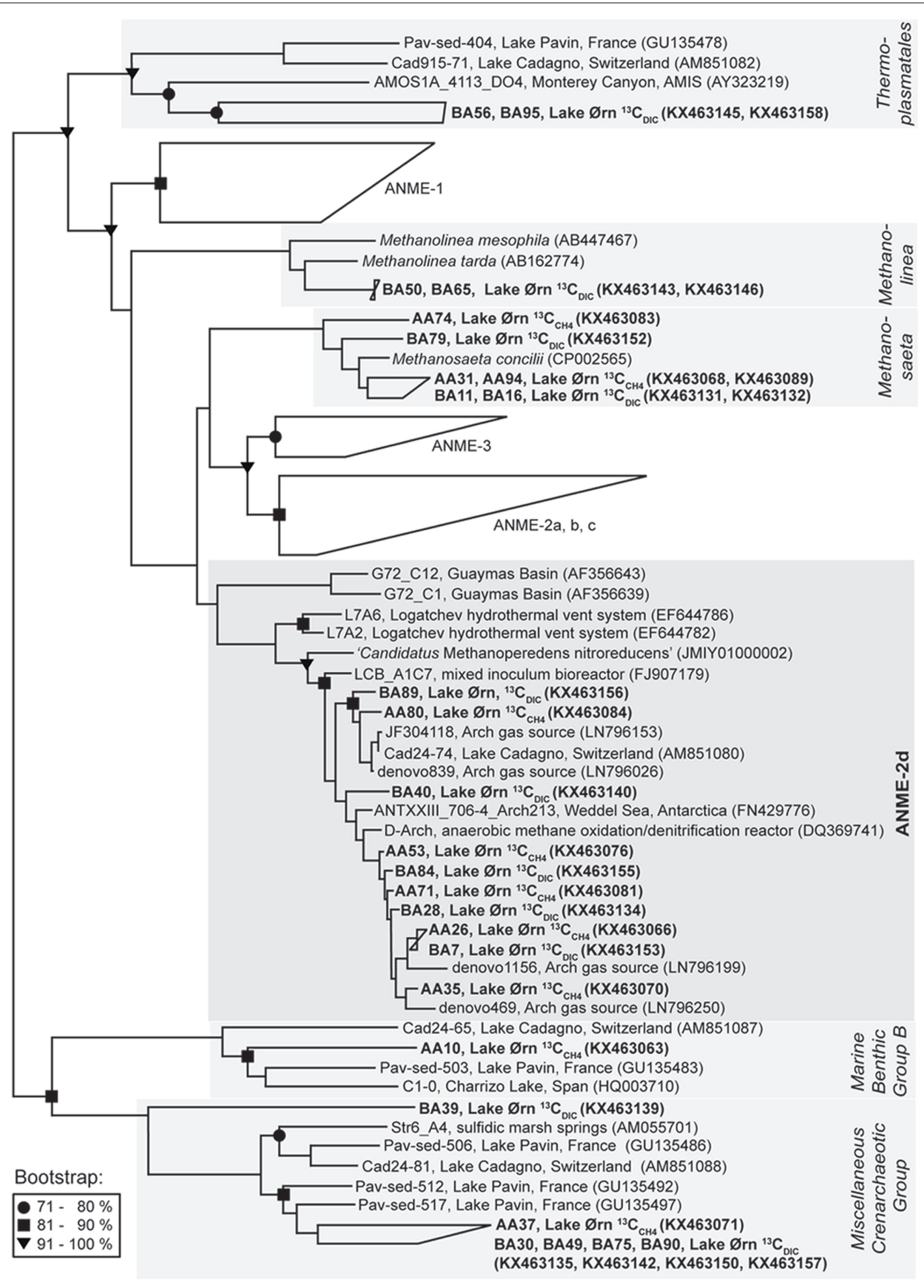

0.1

FIGURE 4 | Neighbor-joining $16 \mathrm{~S}$ rRNA phylogenetic reconstruction for ${ }^{13} \mathrm{C}$-labeled sequences obtained from ${ }^{13} \mathrm{C}_{\mathrm{CH}}$ and ${ }^{13} \mathrm{C}_{\mathrm{DIC}} \mathrm{RNA}$ stable isotope probing incubations and nearest related phylogenetic groups with Hydrogenobaculum acidophilum as outgroup; in brackets: Gene Bank accession numbers. For the cluster ANME-2d 10 of 39 sequences were chosen for display. Bootstrap values (\%) represent the percentage of 1000 repetitions and scale bar shows $10 \%$ distance. 
also falls into Methanosarcinales (Barber et al., 2011), while one was affiliated to Marine Benthic Group B in the phylum Crenarchaeota and was most closely related to clones from other lakes including AOM-active sediment from Lake Cadagno in Switzerland (Schubert et al., 2011). Most ANME-2d clones fell within a single OTU (Supplementary Table S1) and all were also closely related to AAA sequences retrieved from Lake Cadagno sediment (Schubert et al., 2011), sequences retrieved from a freshwater gas source (Timmers et al., 2016) and from the AOM zone of Antarctic cold seep sediments (Niemann et al., 2009). Furthermore, Lake Ørn ANME-2d sequences clustered with sequences derived from denitrifying methane-oxidizing bioreactors (Raghoebarsing et al., 2006; Hu et al., 2009) and with the freshwater nitrate-reducing anaerobic methane oxidizer 'Candidatus Methanoperedens nitroreducens' (Haroon et al., 2013).

A $16 \mathrm{~S}$ rRNA clone library from the ${ }^{13} \mathrm{C}$ fraction of the ${ }^{13} \mathrm{C}_{\text {DIC }}$ slurry incubation yielded 29 sequences of which $\sim 83 \%$ fell into the phylum Euryarchaeota and $\sim 17 \%$ fell into the phylum Crenarchaeota (Figure 4, Table 1 and Supplementary Table S1). The majority of the euryarchaeotic sequences again fell into Methanosarcinales and therein mainly into the group ANME-2d, together with the ANME-2d sequences retrieved from the ${ }^{13} \mathrm{C}$ peak of the ${ }^{13} \mathrm{C}_{\mathrm{CH}} 4$ incubation, as described above. A smaller amount of sequences from the ${ }^{13} \mathrm{C}$ peak with ${ }^{13} \mathrm{C}_{\mathrm{DIC}}$ fell into the genus Methanosaeta and clustered together with the sequences from heavy fraction of the ${ }^{13} \mathrm{C}_{\mathrm{CH} 4}$ incubation and the aceticlastic methanogen Methanosaeta concilii (Barber et al., 2011). Furthermore, a few sequences of the ${ }^{13} \mathrm{C}$ fraction of the ${ }^{13} \mathrm{C}_{\mathrm{DIC}}$ slurry incubation affiliated with Thermoplasmatales and the methanogenic genus Methanolinea. All ${ }^{13} \mathrm{C}$-labeled crenarchaeotic sequences from the ${ }^{13} \mathrm{C}_{\mathrm{DIC}}$ incubation fell into Miscellaneous Crenarchaeotic Group.

Comparison of $16 \mathrm{~S}$ rRNA from the ${ }^{13} \mathrm{C}$ peak fractions to that from the ${ }^{12} \mathrm{C}$ peak of the ${ }^{13} \mathrm{C}_{\mathrm{CH} 4}$ and ${ }^{13} \mathrm{C}_{\mathrm{DIC}}$ incubations further confirmed the selective ${ }^{13} \mathrm{C}$ labeling of the cluster ANME-2d. The ${ }^{12} \mathrm{C}$-peak clone libraries contained 40 and 36 clones from the ${ }^{13} \mathrm{C}_{\mathrm{CH} 4}$ and ${ }^{13} \mathrm{C}_{\mathrm{DIC}}$ incubation, respectively. Similar to the initial communities, about half of the total sequences clustered in the Miscellaneous Crenarchaeotic Group. In total $\sim 20 \%$ of the sequences clustered in Euryarchaeota and were assigned to Thermoplasmatales, except one sequence that was assigned to Methanosaeta and one sequence that was assigned to ANME-2d in the ${ }^{13} \mathrm{C}_{\mathrm{CH}}$ incubation. The rest of the sequences were assigned to Miscellaneous Euryarchaeotic Group and Aenigmarchaeota.

Transcription, PCR amplification, and terminal restriction fragment length polymorphism analyses were carried out for the same samples that were used to construct 16S rRNA clone libraries with the aim to obtain a representation of the entire archaeal community (Supplementary Figure S3). Overall, a large part of the archaeal community could be taxonomically identified based on the predicted T-RF length both for incubation start and after incubation with the ${ }^{13} \mathrm{C}$-labeled substrates. At incubation start, 69 and $77 \%$ of the OTUs in core and slurry, respectively, could be aligned with the OTUs obtained from the $16 \mathrm{~S}$ rRNA clone libraries. In the ${ }^{13} \mathrm{C}_{\mathrm{CH}} 4$ core incubation, $\sim 74 \%$ of the OTUs retrieved from the ${ }^{13} \mathrm{C}$ peak and in the ${ }^{13} \mathrm{C}_{\mathrm{DIC}}$ slurry incubation $\sim 69 \%$ of the OTUs retrieved from the ${ }^{13} \mathrm{C}$ peak could be taxonomically identified. The Supplementary section provides a detailed discussion about the T-RFLP data (Supplementary Table S2) and an overview over the archaea identified in Lake Ørn sediment in the present study.

\section{DISCUSSION}

\section{Methane and Sulfur Turnover In Situ and in Incubations}

Anaerobic consumption of methane in Lake Ørn sediment was indicated in the depth interval of $5-15 \mathrm{~cm}$ by the concave increase of methane concentrations with depth and confirmed by radiotracer incubations and stable isotope analyses in previous reports (Norði et al., 2013; Weber et al., 2016). Nitrate can be excluded as electron acceptor for AOM as it was depleted within the upper $2 \mathrm{~cm}$ of the sediment (Norði et al., 2013). As potential electron acceptors for AOM in Lake Ørn, both sulfate and poorly crystalline ferric iron were previously discussed (Norði et al., 2013; Weber et al., 2016). However, elevated sulfate reduction rates in the AOM zone and a methane-dependent alteration of $\delta^{34} \mathrm{~S}$ signatures in slurry incubations directly implicated sulfate as electron acceptor for AOM while a coupling to iron might be indirect via an iron(III)-dependent cryptic sulfur cycle (Weber et al., 2016).

We chose to focus on the depth interval with the highest in situ AOM activities (10-15 cm, Figures 2E, 3E; see also Norði et al., 2013; Weber et al., 2016) in both cores and slurries with the aim of exploiting the different advantages of each of these two incubation types. Generally, in core incubations, the microbial communities are maintained in the natural biogeochemical gradients and largely protected from mechanical disturbances. However, the quantification of biogeochemical processes in a defined interval is rather difficult as porewater and gaseous parameters are strongly impacted by diffusion along concentration gradients, and core-to-core variability adds noise to the temporal changes observed. Higher controllability can be achieved in slurry incubations where the addition of medium can also support the enrichment of a preferred part of the microbial community. Disadvantages of slurring are physical disturbances of the microbial community and the blockage of diffusion of products and substrates such as, e.g., sulfate due to the closed system.

Anaerobic oxidation of methane and SR were active in all incubations and their rates as obtained from radiotracer incubations were comparable between cores and slurries (Figures 2D,E, 3D,E). The net consumption of sulfate in all slurry incubations and an overall tendency of sulfate to decrease in the core incubations further confirmed microbial reduction of sulfate. Still, radiotracer-based rates exceeded the rate of sulfate depletion substantially, indicating active reoxidation of 
sulfide as previously discussed for this site (Norði et al., 2013; Weber et al., 2016). Similarly, a net accumulation of methane occurred in most incubations and suggested a cooccurrence of AOM and methanogenesis in the layer of sulfate depletion. Based on the similarity to the previous analyses of AOM in Lake Ørn we conclude that AOM in our incubations was likely coupled to sulfate reduction, at least in part, but also that a direct coupling to iron reduction cannot be excluded.

\section{ANME-2d Assimilated ${ }^{13} \mathrm{C}_{\mathrm{CH} 4}$-derived ${ }^{13} \mathrm{C}$}

In the sediment core incubations, ${ }^{13} \mathrm{C}$ was assimilated into $16 \mathrm{~S}$ rRNA after ${ }^{13} \mathrm{C}_{\mathrm{CH} 4}$ addition, giving rise to a high-density peak in the density gradient, while radiotracer incubations confirmed AOM activity. Far most of the ${ }^{13} \mathrm{C}$-labeled sequences fell into the euryarchaeotic order Methanosarcinales and therein grouped tightly in the cluster ANME-2d (Figure 4 and Table 1). Sequences falling into ANME-2d were also part of the active initial archaeal community, $12 \%$ of clones, whereas strains from other ANME groups were not detected. The presence of ANME-2d in the $16 \mathrm{~S}$ rRNA clone libraries of the untreated sediment and the strong enrichment of this group in the high-density fraction obtained from ${ }^{13} \mathrm{C}$ labeling, indicated that ANME-2d carry out AOM in Lake Ørn sediment. This was further supported by the lack of detectable RNA in the high-density fractions of the parallel incubation without ${ }^{13} \mathrm{C}$ source (Lueders et al., 2004).

Members of this cluster were previously observed in AOMactive habitats, but due to lacking evidence of their methaneoxidizing capabilities, they were first grouped with uncultured methanogens in a clade named GOM Arc 1 (Lloyd et al., 2006). Subsequently, the identification of $16 \mathrm{~S}$ rRNA sequences associated with nitrate-dependent AOM archaea in a bioreactor enrichment (Raghoebarsing et al., 2006) resulted in identification of the cluster named AOM-Associated Archaea (AAA) as a subgroup of GOM ARC 1 (Knittel and Boetius, 2009). The group AAA was renamed ANME-2d after the genetic reconstruction of 'Cand. M. nitroreducens', with the capability to reduce nitrate while oxidizing methane via the reverse methanogenesis pathway (Haroon et al., 2013).

In Lake Ørn, nitrate can be excluded as electron acceptor for AOM (Norði et al., 2013), suggesting that the detected ANME$2 \mathrm{~d}$ strains most likely coupled methane oxidation to sulfate and/or iron reduction. Ferric iron-dependent AOM was recently reported in an enriched ANME-2d/AAA strain (Ettwig et al., 2016). However, a coupling of ANME-2d to sulfur cycling cannot be conclusively excluded as this group was also detected in a range of marine sulfur-cycling environments including, e.g., the Logatchev hydrothermal vent system (Voordeckers et al., 2008), deep-sea marine sediments (e.g., Inagaki et al., 2006), and Antarctic cold seep sediments (Niemann et al., 2009). Further ANME-2d sequences were reported from freshwater systems characterized by active sulfur-cycling at lower sulfate concentrations as, e.g., in sediment of the alpine Lake Cadagno (originally described as AAA; Schubert et al., 2011), in freshwater wells (Flynn et al., 2013), and in freshwater gas sources (Timmers et al., 2016).
Although we cannot link the members of ANME-2d identified in Lake Ørn to either sulfate or ferric iron reduction with certainty, the present study is, to our knowledge, the first to experimentally associate ANME-2d activity to AOM in a natural environment by following the incorporation of ${ }^{13} \mathrm{C}_{\mathrm{CH}} 4$ into biomass, and to demonstrate that this activity is possible in the absence of nitrate.

In the ${ }^{13} \mathrm{C}_{\mathrm{CH} 4}$ incubation, a small number of sequences clustering with Methanosaeta, Marine Benthic Group, and Miscellaneous Crenarchaeotic Group were detected in the highdensity fraction (Figure 4, Table 1 and Supplementary Table S1). As these groups were not clearly enriched in the high-density fraction relative to the original community, they may represent the carryover of small amounts of unlabeled RNA to the ${ }^{13} \mathrm{C}$ peak, which is typical for the method and possibly due to interaction with ${ }^{13}$ C-labeled RNA (Lueders et al., 2004). The same consideration applies to the minor groups detected in the heavy fraction of the ${ }^{13} \mathrm{C}_{\text {DIC }}$ incubation (Figure 4, Table 1 and Supplementary Table S1). Like previous RNA-SIP studies (Hori et al., 2007; Gutierrez et al., 2015), we therefore exclude these minor groups from both treatments from further discussion.

\section{Incorporation of ${ }^{13} \mathrm{C}_{\mathrm{CH} 4}$ - and ${ }^{13} \mathrm{C}_{\text {DIC-derived }}{ }^{13} \mathrm{C}$ into ANME-2d Strains: Mixotrophy or Cross-feeding?}

Reverse methanogenesis as the pathway for anaerobic methane oxidation in ANME strains including ANME-2d is known on a detailed enzymatic level (Hallam et al., 2004; Haroon et al., 2013; Arshad et al., 2015). Furthermore, as shown in the present study, members of the ANME-2d cluster can assimilate $\mathrm{CH}_{4}$ and incorporate it into biomass. However, from our ${ }^{13} \mathrm{C}_{\mathrm{DIC}}$ slurry, we obtained ${ }^{13} \mathrm{C}$-enriched $16 \mathrm{~S}$ rRNA sequences affiliated to ANME-2d and therein clustering with the sequences obtained in the ${ }^{13} \mathrm{C}_{\mathrm{CH} 4}$ core incubation. This finding suggests that ANME-2d strains are either capable of a mixed assimilation of $\mathrm{CH}_{4}$ and DIC and/or that cross-feeding of ${ }^{13} \mathrm{C}$-labeled metabolites could potentially have occurred.

Cross-feeding of labeled substrates is a general risk in stable isotope probing incubations (Dumont and Murrell, 2005 and references therein). In the present study, cross-feeding could potentially have occurred in two directions: (1) in the ${ }^{13} \mathrm{C}_{\mathrm{CH}} 4$ incubations, AOM activity could have lead to the build-up of ${ }^{13} \mathrm{C}_{\mathrm{DIC}}$, which could have been assimilated by autotrophic microorganisms, e.g., by hydrogenotrophic methanogens, being falsely understood as methanotrophs. On the other hand, (2) in the ${ }^{13} \mathrm{C}_{\text {DIC }}$ incubations, methanogens could have built up significant amounts of ${ }^{13} \mathrm{C}_{\mathrm{CH} 4}$ and ${ }^{13} \mathrm{C}_{\mathrm{CH} 4}$-assimilating anaerobic methane oxidizers could have been falsely interpreted as autotrophs. We exclude case (1) because the highest accumulation of ${ }^{13} \mathrm{C}$ in the DIC pool achieved during the incubation would be insufficient to explain our observations. Thus, with an average AOM rate of $3 \mathrm{nmol} \mathrm{cm}^{-3}$ day $^{-1}$ in the $10-15 \mathrm{~cm}$ layer of the ${ }^{13} \mathrm{C}_{\mathrm{CH} 4}$ incubated core (Figure 2), over the incubation period of 30 days, the amount of ${ }^{13} \mathrm{C}_{\mathrm{DIC}}$ generated by AOM would have reached only $\sim 3$ atom-\% of the total DIC pool $\left(\sim 3 \mathrm{mmol} \mathrm{L} \mathrm{L}^{-1}\right.$, data not shown) at the 
end of incubation, while 20 atom-\% labeling is generally needed to shift a RNA sequence from the ${ }^{12} \mathrm{C}$ to the ${ }^{13} \mathrm{C}$ fraction in the CsTFA gradient (Manefield et al., 2011). A similar estimate can be performed to evaluate (2) cross-feeding in the ${ }^{13} \mathrm{C}_{\mathrm{DIC}}$ incubations: as there was no significant net change in methane concentrations in the ${ }^{13} \mathrm{C}_{\mathrm{DIC}}$ slurry incubations, one can assume that methanogenic activity may have approximately equalled the activity of anaerobic methanotrophs. As a consequence, over an incubation time of 72 days, with an average rate of $5 \mathrm{nmol}$ $\mathrm{cm}^{-3}$ day $^{-1}$ and the DIC pool being ${ }^{13} \mathrm{C}$ enriched by $\sim 25 \%$, methanogens could have built up $>100 \mu \mathrm{mol} \mathrm{L}{ }^{-1}$ of ${ }^{13} \mathrm{C}_{\mathrm{CH} 4}$ which would have been sufficient for cross-feeding under the prevailing methane conditions. Therefore, it appears evident that ANME-2d in Lake Ørn directly assimilated ${ }^{13} \mathrm{C}_{\mathrm{CH} 4}$, but the apparent ${ }^{13} \mathrm{C}_{\mathrm{DIC}}$ assimilation by the same strain may be a result of ${ }^{13} \mathrm{CH}_{4}$ incorporation after methanogenesis from ${ }^{13} \mathrm{C}_{\text {DIC }}$.

Mixed assimilation of $\mathrm{CH}_{4}$ and $\mathrm{CO}_{2}$ has been reported for ANME-2a and $-2 \mathrm{c}$ strains retrieved from marine environments, but with a preferred usage of $\mathrm{CO}_{2}$ over $\mathrm{CH}_{4}$ for biomass production (Wegener et al., 2008; Milucka et al., 2012). Thus, ANME-2 strains of a long-term enrichment culture incorporated both $\mathrm{CO}_{2}$ and $\mathrm{CH}_{4}$ into their biomass, but with a 25-times higher rate for $\mathrm{CO}_{2}$ in comparison to $\mathrm{CH}_{4}$ (Milucka et al., 2012). A complete decoupling of methane oxidation from the assimilatory system and autotrophy instead of mixotrophy was proposed for a group of ANME-1 strains from hydrothermal sediments in Guaymas Basin (Kellermann et al., 2012). It remains unclear if the preference of the carbon source for assimilation is strain-specific or/and impacted by environmental conditions. Our observation of incorporation of ${ }^{13} \mathrm{C}$ into RNA of ANME-2d in both ${ }^{13} \mathrm{C}_{\mathrm{CH} 4}$ and ${ }^{13} \mathrm{C}_{\mathrm{DIC}}$ incubations suggests that carbon flow in the ANME-2d cells may differ from that in the previously studied ANME-1, $-2 \mathrm{a}$, and $-2 \mathrm{c}$ strains. However, the difference in labeling pattern between cores and slurries might further indicate a metabolic shift of the AOM-mediating community caused by the different types of incubation, as the ${ }^{13} \mathrm{C}$ sources were added in comparable amounts in slurry and core incubations and samples were treated consistently. The previous studies were all carried out in slurry incubations or enrichment cultures (Wegener et al., 2008; Kellermann et al., 2012; Milucka et al., 2012). Their results were in agreement with the results of our slurry incubations that only showed ${ }^{13} \mathrm{C}$-enriched RNA with ${ }^{13} \mathrm{C}_{\mathrm{DIC}}$-amendment and therefore also indicated preferred assimilation of $\mathrm{CO}_{2}$. We conclude that, members of ANME-2d may have the potential for mixed assimilation of $\mathrm{CH}_{4}$ and $\mathrm{CO}_{2}$, but further investigations are required to identify if such a metabolism would be strainspecific or a physiological response to changing biogeochemical environments.

\section{REFERENCES}

Arshad, A., Speth, D. R., De Graaf, R. M., Op den Camp, H. J. M., Jetten, M. S., and Welte, C. U. (2015). A metagenomics-based metabolic model of nitratedependent anaerobic oxidation of methane by Methanoperedens-like archaea. Front. Microbiol. 6:1423. doi: 10.3389/fmicb.2015.01423

\section{CONCLUSION}

In freshwater environments, AOM was only recently shown to substantially reduce methane emissions from sediment and prevents its flux into the atmosphere (Norði et al., 2013; Segarra et al., 2013; Deutzmann et al., 2014). In Lake Ørn, AOM was active below the nitrate-containing zone and under low-sulfate, iron-rich conditions (Norði et al., 2013; Weber et al., 2016) and carried out by anaerobic methane oxidizers belonging to the cluster ANME-2d. We showed that members of ANME$2 \mathrm{~d}$ are active under natural conditions and own the enzymatic capabilities to assimilate $\mathrm{CH}_{4}$ and probably also $\mathrm{CO}_{2}$ into their biomass. Our results place members ANME-2d as prime candidates for AOM in low-sulfate iron-rich environments, and thereby as potentially important players in the regulation of methane emissions from freshwater systems. Further studies of this clade in Lake Ørn and other freshwater environments might help to solve the puzzle of the pathways involved in anaerobic methanotrophy in such systems.

\section{AUTHOR CONTRIBUTIONS}

$\mathrm{HW}, \mathrm{KH}$, and BT designed research, analyzed and interpreted the data, and wrote the manuscript. HW carried out field work and laboratory-based research.

\section{FUNDING}

We are grateful to the Danish National Research Foundation (DNRF53) and the Danish Council for Independent Research for supporting this work.

\section{ACKNOWLEDGMENTS}

We acknowledge Michael Forth for his help sampling the sediment and for his assistance in the laboratory. We thank Laura Bristow and Nicole Posth for establishing and testing the method for determination of the stable isotope ratio of ${ }^{13} \mathrm{C} /{ }^{12} \mathrm{C}$ in DIC.

\section{SUPPLEMENTARY MATERIAL}

The Supplementary Material for this article can be found online at: http://journal.frontiersin.org/article/10.3389/fmicb. 2017.00619/full\#supplementary-material

Barber, R. D., Zhang, L., Harnack, M., Olson, M. V., Kaul, R., Ingram-Smith, C., et al. (2011). Complete genome sequence of Methanosaeta concilii, a specialist in aceticlastic methanogenesis. J. Bacteriol. 193, 3668-3669. doi: 10.1128/JB. 05031-11

Beal, E. J., Claire, M. W., and House, C. H. (2011). High rates of anaerobic methanotrophy at low sulfate concentrations with implications for past and 
present methane levels. Geobiology 9, 131-139. doi: 10.1111/j.1472-4669.2010. 00267.x

Beal, E. J., House, C. H., and Orphan, V. J. (2009). Manganese- and iron-dependent marine methane oxidation. Science 325, 184-187. doi: 10.1126/science.1169984

Boetius, A., Ravenschlag, K., Schubert, C. J., Rickert, D., Widdel, F., Gieseke, A., et al. (2000). A marine microbial consortium apparently mediating anaerobic oxidation of methane. Nature 407, 623-626. doi: 10.1038/35036572

De Brabandere, L., Thamdrup, B., Revsbech, N. P., and Foadi, R. (2012). A critical assessment of the occurrence and extend of oxygen contamination during anaerobic incubations utilizing commercially available vials. J. Microbiol. Methods 88, 147-154. doi: 10.1016/j.mimet.2011.11.001

Deutzmann, J. S., Stief, P., Brandes, J., and Schink, B. (2014). Anaerobic methane oxidation coupled to denitrification is the dominant methane sink in a deep lake. Proc. Natl. Acad. Sci. U.S.A. 111, 18273-18278. doi: 10.1073/pnas. 1411617111

Dumont, M. G., and Murrell, J. C. (2005). Stable isotope probing - linking microbial identity to function. Nat. Rev. Microbiol. 3, 499-504. doi: 10.1038/ nrmicro1162

Egger, M., Rasigraf, O., Sapart, C. J., Jilbert, T., Jetten, M. S., Röckmann, T., et al. (2015). Iron-mediated anaerobic oxidation of methane in brackish coastal sediments. Environ. Sci. Technol. 49, 277-283. doi: 10.1021/es503663z

Ettwig, K. F., Butler, M. K., Le Paslier, D., Pelletier, E., Mangenot, S., Kuypers, M. M. M., et al. (2010). Nitrite-driven anaerobic methane oxidation by oxygenic bacteria. Nature 464, 543-548. doi: 10.1038/nature08883

Ettwig, K. F., Zhu, B., Speth, D., Keltjens, J. T., Jetten, M. S. M., and Kartal, B. (2016). Archaea catalyze iron-dependent anaerobic oxidation of methane. Proc. Natl. Acad. Sci. U.S.A. doi: 10.1073/pnas.1609534113 [Epub ahead of print].

Flynn, T. M., Sanford, R. A., Ryu, H., Bethke, C. M., Levine, A. D., Ashbolt, N. J., et al. (2013). Functional microbial diversity explains groundwater chemistry in a pristine aquifer. BMC Microbiol. 13, 1-15. doi: 10.1186/1471-2180-13-146

Gutierrez, T., Biddle, J. F., Teske, A., and Aitken, M. D. (2015). Cultivationdependent and cultivation-independent characterization of hydrocarbondegrading bacteria in Guaymas Basin sediments. Front. Microbiol. 6:695. doi: 10.3389/fmicb.2015.00695

Hallam, S. J., Putnam, N., Preston, C. M., Detter, J. C., Rokhsar, D., Richardson, P. M., et al. (2004). Reverse methanogenesis: testing the hypothesis with environmental genomics. Science 305, 1457-1462. doi: 10.1126/science.1100025

Haroon, M. F., Hu, S., Shi, Y., Imelfort, M., Keller, J., Hugenholtz, P., et al. (2013). Anaerobic oxidation of methane coupled to nitrate reduction in a novel archaeal lineage. Nature 500, 567-570. doi: 10.1038/nature12375

Hinrichs, K.-U., Hayes, J. M., Sylva, S. P., Brewer, P. G., and DeLong, E. F. (1999). Methane-consuming archaebacteria in marine sediments. Nature 398, 802-805. doi: $10.1038 / 19751$

Holmkvist, L., Ferdelman, T. G., and Jørgensen, B. B. (2011). A cryptic sulfur cycle driven by iron in the methane zone of marine sediment (Aarhus Bay, Denmark). Geochim. Cosmochim. Acta 75, 3581-3599. doi: 10.1016/j.gca.2011.03.033

Hori, T., Noll, M., Igarashi, Y., Friedrich, M. W., and Conrad, R. (2007). Identification of acetate-assimilating microorganisms under methanogenic conditions in anoxic rice field soil by comparative stable isotope probing of RNA. Appl. Environ. Microbiol. 73, 101-109. doi: 10.1128/AEM.01676-06

Hu, S., Zeng, R. J., Burow, L. C., Lant, P., Keller, J., and Yuan, Z. (2009). Enrichment of denitrifying anaerobic methane oxidizing microorganisms. Environ. Microbiol. Rep. 1, 377-384. doi: 10.1111/j.1758-2229.2009.00083.x

Huber, T., Faulkner, G., and Hugenholtz, P. (2004). Bellerophon: a program to detect chimeric sequences in multiple sequence alignments. Bioinformatics 20, 2317-2319. doi: 10.1093/bioinformatics/bth226

Inagaki, F., Nunoura, T., Nakagawa, S., Teske, A., Lever, M., Lauer, A., et al. (2006). Biogeographical distribution and diversity of microbes in methane hydratebearing deep marine sediments on the Pacific Ocean Margin. Proc. Natl. Acad. Sci. U.S.A. 103, 2815-2820. doi: 10.1073/pnas.0511033103

Jørgensen, B. B. (1978). Comparison of methods for quantification of bacterial sulfate reduction in coastal marine sediments. 1 . Measurement with radiotracer techniques. Geomicrobiol. J. 1, 11-27.

Kallmeyer, J., Ferdelman, T. G., Weber, A., Fossing, H., and Jørgensen, B. B. (2004). A cold chromium distillation procedure for radiolabeled sulfide applied to sulfate reduction measurements. Limnol. Oceanogr. Methods 2, 171-180. doi: $10.4319 /$ lom.2004.2.171
Kellermann, M. Y., Wegener, G., Elvert, M., Yoshinaga, M. Y., Lin, Y.-S., Holler, T., et al. (2012). Autotrophy as a predominant mode of carbon fixation in anaerobic methane-oxidizing microbial communities. Proc. Natl. Acad. Sci. U.S.A. 109, 19321-19326. doi: 10.1073/pnas.1208795109

Knittel, K., and Boetius, A. (2009). Anaerobic oxidation of methane: progress with an unknown process. Annu. Rev. Microbiol. 63, 311-334. doi: 10.1146/annurev. micro.61.080706.093130

Lloyd, K. G., Lapham, L., and Teske, A. (2006). An anaerobic methane-oxidizing community of ANME-1b archaea in hypersaline Gulf of Mexico sediments. Appl. Environ. Microbiol. 72, 7218-7230. doi: 10.1128/AEM.00886-06

Ludwig, W., Strunk, O., Westram, R., Richter, L., Meier, H., Yadhukumar, et al. (2004). ARB: a software environment for sequence data. Nucleic Acids Res. 32, 1363-1371. doi: 10.1093/nar/gkh293

Lueders, T., Manefield, M., and Friedrich, M. W. (2004). Enhanced sensitivity of DNA- and rRNA-based stable isotope probing by fractionation and quantitative analysis of isopycnic centrifugation gradients. Environ. Microbiol. 6, 73-78. doi: 10.1046/j.1462-2920.2003.00536.x

Manefield, M., Gutierrez-Zamora, M.-L., and Whiteley, A. S. (2011). "RNA stable isotope probing," in Stable Isotope Probing and Related Technologies, eds J. C. Murrell and A. S. Whiteley (Washington, DC: ASM Press), 25-36.

McGlynn, S. E., Chadwick, G. L., Kempes, C. P., and Orphan, V. J. (2015). Single cell activity reveals direct electron transfer in methanotrophic consortia. Nature 526, 531-535. doi: 10.1038/nature 15512

Meulepas, R. J. W., Jagersma, C. G., Khadem, A. F., Stams, A. J. M., and Lens, P. N. L. (2010). Effect of methanogenic substrates on anaerobic oxidation of methane and sulfate reduction by an anaerobic methanotrophic enrichment. Appl. Microbiol. Biotechnol. 87, 1499-1506. doi: 10.1007/s00253-010-2597-0

Milucka, J., Ferdelman, T. G., Polerecky, L., Franzke, D., Wegener, G., Schmid, M., et al. (2012). Zero-valent sulphur is a key intermediate in marine methane oxidation. Nature 491, 541-546. doi: 10.1038/nature11656

Niemann, H., Fischer, D., Graffe, D., Knittel, K., Montiel, A., Heilmayer, O., et al. (2009). Biogeochemistry of a low-activity cold seep in the Larsen B area, western Weddell Sea, Antarctica. Biogeosciences 6, 2383-2395. doi: 10.5194/bg-6-23832009

Norðði, K. Á., Thamdrup, B., and Schubert, C. J. (2013). Anaerobic oxidation of methane in an iron-rich Danish freshwater lake sediment. Limnol. Oceanogr. 58, 546-554. doi: 10.4319/lo.2013.58.2.0546

Oni, O., Miyatake, T., Kasten, S., Richter-Heitmann, T., Fischer, D., Wagenknecht, L., et al. (2015). Distinct microbial populations are tightly linked to the profile of dissolved iron in the methanic sediments of the Helgoland mud area, North Sea. Front. Microbiol. 6:365. doi: 10.3389/fmicb.2015.00365

Orphan, V. J., House, C. H., Hinrichs, K.-U., McKeegan, K. D., and DeLong, E. F. (2002). Multiple archaeal groups mediate methane oxidation in anoxic cold seep sediments. Proc. Natl. Acad. Sci. U.S.A. 99, 7663-7668. doi: 10.1073/pnas. 072210299

Pruesse, E., Quast, C., Knittel, K., Fuchs, B. M., Ludwig, W., and Glöckner, F. O. (2007). SILVA: a comprehensive online resource for quality checked and aligned ribosomal RNA sequence data compatible with ARB. Nucleic Acids Res. 35, 7188-7196. doi: 10.1093/nar/gkm864

Raghoebarsing, A. A., Pol, A., Van de Pas-Schoonen, K. T., Smolders, A. J. P., Ettwig, K. F., Rijpstra, W. I. C., et al. (2006). A microbial consortium couples anaerobic methane oxidation to denitrification. Nature 440, 918-921. doi: 10. 1038/nature04617

Riedinger, N., Brunner, B., Formolo, M. J., Solomon, E., Kasten, S., Strasser, M., et al. (2010). Oxidative sulfur cycling in the deep biosphere of the Nankai Trough, Japan. Geology 38, 851-854. doi: 10.1130/G31085.1

Riedinger, N., Formolo, M. J., Lyons, T. W., Henkel, S., Beck, A., and Kasten, S. (2014). An inorganic geochemical argument for coupled anaerobic oxidation of methane and iron reduction in marine sediments. Geobiology 12, 172-181. doi: 10.1111/gbi.12077

Røy, H., Weber, H. S., Tarpgaard, I. H., Ferdelman, T. G., and Jørgensen, B. B. (2014). Determination of dissimilatory sulfate reduction rates in marine sediment via radioactive 35 S tracer. Limnol. Oceanogr. Methods 12, 196-211. doi: 10.4319/lom.2014.12.196

Scheller, S., Yu, H., Chadwick, G. L., McGlynn, S. E., and Orphan, V. J. (2016). Artificial electron acceptors decouple archaeal methane oxidation from sulfate reduction. Science 351, 703-707. doi: 10.1126/science.aad7154 
Schubert, C. J., Vazquez, F., Lösekann-Behrens, T., Knittel, K., Tonolla, M., and Boetius, A. (2011). Evidence for anaerobic oxidation of methane in sediments of a freshwater system (Lago Di Cadagno). FEMS Microbiol. Ecol. 76, 26-38. doi: 10.1111/j.1574-6941.2010.01036.x

Segarra, K. E. A., Comerford, C., Slaughter, J., and Joye, S. B. (2013). Impact of electron acceptor availability on the anaerobic oxidation of methane in coastal freshwater and brackish wetland sediments. Geochim. Cosmochim. Acta 115, 15-30. doi: 10.1016/j.gca.2013.03.029

Sivan, O., Adler, M., Pearson, A., Gelman, F., Bar-Or, I., John, S. G., et al. (2011). Geochemical evidence for iron-mediated anaerobic oxidation of methane. Limnol. Oceanogr. 56, 1536-1544. doi: 10.4319/lo.2011.56.4.1536

Skovgaard, H. (2004). “Ørn Sø 2003”. Environment Monitoring Report, County of Aarhus Department of Nature and Environment, Højbjerg, 63.

Timmers, P. H., Suarez-Zuluaga, D. A., Van Rossem, M., Diender, M., Stams, A. J., and Plugge, C. M. (2016). Anaerobic oxidation of methane associated with sulfate reduction in a natural freshwater gas source. ISME J. 10, 1400-1412. doi: 10.1038/ismej.2015.213

Treude, T., Krüger, M., Boetius, A., and Jørgensen, B. B. (2005). Environmental control on anaerobic oxidation of methane in the gassy sediments of Eckernförde Bay (German Baltic). Limnol. Oceanogr. 50, 1771-1786. doi: $10.4319 /$ lo.2005.50.6.1771

Voordeckers, J. W., Do, M. H., Hügler, M., Ko, V., Sievert, S. M., and Vetriani, C. (2008). Culture dependent and independent analyses of 16S rRNA and ATP citrate lyase genes: a comparison of microbial communities from different black smoker chimneys on the Mid-Atlantic Ridge. Extremophiles 12, 627-640. doi: 10.1007/s00792-008-0167-5
Weber, H. S., Thamdrup, B., and Habicht, K. S. (2016). High sulfur isotope fractionation associated with anaerobic oxidation of methane in a lowsulfate, iron-rich environment. Front. Earth Sci. 4:61. doi: 10.3389/feart.2016. 00061

Wegener, G., Krukenberg, V., Riedel, D., Tegetmeyer, H. E., and Boetius, A. (2015). Intercellular wiring enables electron transfer between methanotrophic archaea and bacteria. Nature 526, 587-589. doi: 10.1038/nature 15733

Wegener, G., Niemann, H., Elvert, M., Hinrichs, K.-U., and Boetius, A. (2008). Assimilation of methane and inorganic carbon by microbial communities mediating the anaerobic oxidation of methane. Environ. Microbiol. 10, 2287-2298. doi: 10.1111/j.1462-2920.2008.01653.x

Whiteley, A. S., Thomson, B., Lueders, T., and Manefield, M. (2007). RNA stable-isotope probing. Nat. Protoc. 2, 838-844. doi: 10.1038/nprot. 2007.115

Conflict of Interest Statement: The authors declare that the research was conducted in the absence of any commercial or financial relationships that could be construed as a potential conflict of interest.

Copyright (c) 2017 Weber, Habicht and Thamdrup. This is an open-access article distributed under the terms of the Creative Commons Attribution License (CC BY). The use, distribution or reproduction in other forums is permitted, provided the original author(s) or licensor are credited and that the original publication in this journal is cited, in accordance with accepted academic practice. No use, distribution or reproduction is permitted which does not comply with these terms. 